\title{
Improvement of solanaceous vegetables for nutritional attributes: A review
}

\author{
Vimlesh Kumar $^{* 1}$, D.P. Mishra ${ }^{2}$, Roopam ${ }^{3}$, Shivam ${ }^{4}$ and Komal Yadav ${ }^{5}$ \\ ${ }^{1} \mathrm{Ph} . \mathrm{D}$ Scholar, ${ }^{2}$ Assistant Professor, Department of Vegetable Science, N.D. University of Agriculture \\ and Technology, Kumarganj, Faizabad 224229 (U.P) \\ ${ }^{4} \mathrm{Ph} . \mathrm{D}$. Scholar, Department of Extension Education, N.D. University of Agriculture and Technology, \\ Kumarganj, Faizabad 224229 (U.P) \\ ${ }^{3}$ Ph.D. Scholar, Department of Genetics \& Plant Breeding, CSAUA\&T Kanpur-208002, \\ ${ }^{5} \mathrm{Ph} . \mathrm{D}$. Scholar, Department of Agronomy, GBPUA\&T Pantnagar \\ *Email: vimileshkumaryadav@gmail.com ${ }^{122}$
}

\begin{abstract}
Solanaceous vegetables play a significant role in human nutrition especially as sources of vitamins like vitamin C, A, E, thiamine, niacin, pyridoxine, folacin, minerals and dietry fibre. Besides supplying many nutrients, vegetables provide variety to the diet and make the food attractive by their colour, texture and flavor. They termed as Protective Foods as they are rich in minerals, vitamins and phytonutrients. Traditionally, crop improvement programmes have been focused on yield and disease resistance with limited emphasis on nutritional attributes. However, major antioxidants supplying from solanaceous vegetables like as depends upon their acceptance by the consumers. Nutritional attributes is an essential component of economic yield as it determines the suitability of plant product for various uses and therefore, it is an integral part of plant breeding (Singh, 2004). In tomato, total soluble solids, acidity, ascorbic acid, carotenoids, lycopene, vitamin $\mathrm{C}$ content, reducing sugar and dry matter content inherited Non additive and over dominance (Kalloo, 1986). This group includes tomato, brinjal, chilli, sweet pepper and potato are all time favourite vegetables. Vitamins, Minerals, Phyto-nutrients, Antioxidants, Flavanoids, Carbohydrates, Proteins and Lipids are important nutritional attribute in solanaceous vegetables. In tomato and chilli, ascorbic acid constitute an important nutritional attribute and in these vegetables emphasis should be focused on breeding for ascorbic acid content and other nutritional attribute. In chilli cultivars that AC-588-1 had the highest level of antioxidant followed BCC-62 and AC 465. These cultivars can likely be used as genetic material in future breeding programme (Bhattacharya et al., 2010). In brinjal, as both additive and non additive genetic component were involved in inheritance of anthocyanin, for improvement this character the reciprocal recurrent selection seems to be effective (Chadha et al,.1988).
\end{abstract}

Key words: Breeding, Nutritional attributes, Transgenic, Antioxidant, Inheritance.

Paper cited: Kumar, Vimlesh; Mishra, D.P., Roopam; Shivam and Yadav, Komal (2015). Improvement of solanaceous vegetables for nutritional attributes: A Review. South Asian J. Food Technol. Environ. 1(2): 122-125.

India is the leading vegetable producer in the world occupying an area of 9.20 mha with the production of $162.18 \mathrm{mt}$ (NHB, 2013) and ranks second in vegetable production after China Limited cultivated area, increasing population, and ever increasing pressure on land due to urbanization and industrialization has left us only with one solution i.e. to increase the productivity. Nutrition is nourishment or energy that is obtained from food consumed or the process of consuming the proper amount of nourishment and energy Determine the value of the produce in human/ animal nutrition, includes protein content and quality, oil content and quality, vitamin content, mineral content, etc., and also the presence of anti nutritional factors. Not easily appreciated by consumers and farmers, But they are of paramount value in determining human and animal health. Tomato is universally treated as 'Protective Food' since it is a rich source of minerals, vitamins and organic acids used as raw vegetable in sandwiches, salad etc. and in processed forms like paste and puree. Chilli is most important vegetable and supply ascorbic acid, vitamin A and dietry fibre in daily human diet. Brinjal is rich source of carbohydrates $(4.0 \mathrm{~g} / 100 \mathrm{~g})$ and iron $(0.24 \mathrm{mg} / 100 \mathrm{~g})$. Tuber crops like potato give more calories compared to green leafy vegetables because they contain more carbohydrate that is present in the form of starch. Tuber crops are fairly good source of vitamin $\mathrm{C}$ but poor in protein, calcium, iron and B vitamins.

Nutritional status

Globally $53 \%$ of children of the world are malnourished and underweight and $40 \%$ of them live in India. Worldwide $70 \%$ of malnourished people live in South and Southeast Asia. Nearly 800 million people remain hungry and nearly 1.3 billion live in less than 1US \$/ day. Nearly 19000 infants among 40000 die every day due to malnutrition related 
disorders 3.2 billion live with iron and vitamin ' $\mathrm{A}$ ' deficiency resulting irreversible blindness among 125 million school children. Disease/disorder caused by nutritional deficiency in human is given in Table 1.

\section{Nutritional attributes}

Vitamins: These are organic compounds required by an organism as a vital nutrient in limited amounts. An organic chemical compound (or related set of compounds) is called a vitamin when it cannot be synthesized in sufficient quantities by an organism, and must be obtained from the diet.

Minerals: Minerals are the chemical elements required by living organisms, other than the four elements carbon, hydrogen, nitrogen, and oxygen present in common organic molecules. Minerals in order of abundance in the human body include the seven major minerals calcium, phosphorus, potassium, sulfur, sodium, chlorine, and magnesium. Important "trace" or minor minerals, necessary for mammalian life, include iron, cobalt, copper, zinc, molybdenum, iodine, and selenium'.

Phyto-nutrients: Phytochemicals are those chemical compounds that occur naturally in plants (phyto means "plant" in Greek), are responsible for colour and organoleptic properties, such as the deep purple of blueberries and smell of garlic. The term is generally used to refer to those chemicals that may have biological significance but are not established as essential nutrients.

Antioxidants: An antioxidant is a molecule that inhibits the oxidation of fat molecules. Oxidation is a chemical reaction that transfers electrons or hydrogen from a substance to an oxidizing agent. Oxidation reactions can produce free radicals. In turn, these radicals can start chain reactions. When the chain reaction occurs in a cell, it can cause damage or death to the cell. Antioxidants terminate these chain reactions by removing free radical intermediates, and inhibit other oxidation reactions. Major antioxidant supply from solanaceous vegetables are Vitamin $\mathrm{C}$ (Tomato, Chilli and Sweet pepper), $\beta$-carotene (Bell pepper and Tomato), Lycopene and terpenoids (Tomato), Anthocynin (Blue Swede cultivar of potato and Brinjal) and Phenolic Compounds (Pepper and Egg plant).

Flavanoids: Flavonoids (or bioflavonoids) (from the Latin word flavus meaning yellow, their colour in nature) are a class of plant secondary metabolites.

Dry matter: The dry matter of food would include carbohydrates, fat, protein, vitamins, minerals and antioxidants (e.g., thiocyanate, anthocyanin, and quercetin). Carbohydrates, fat and proteins which provide the energy in foods (measured in kilocalories or kilojoules) make up ninety percent of the dry weight of a diet.
Carbohydrates: A component of food that supplies energy (calories) to the body. Three broad categories of carbohydrates are sugars (also called simple carbohydrates), starches (also called complex carbohydrates) and fiber. Except for fiber and resistant starch, carbohydrates cause more and faster blood glucose rises than the other macronutrients.

Proteins: Proteins are large biological molecules consisting of one or more chains of amino acids. Proteins perform a vast array of functions within living organisms, including catalyzing metabolic reactions, replicating DNA, responding to stimuli and transporting molecules from one location to another.

Lipids: Lipids constitute a broad group of naturally occurring molecules that include fats, waxes, sterols, fat-soluble vitamins (such as vitamins A, D, E, and $\mathrm{K}$ ), monoglycerides, diglycerides, triglycerides and phospholipids.

\section{Donors for nutritional attributes}

Wild and weedy relatives of cultivated Species: Wild relatives of a crop includes its primitive forms (from where they have originated), related weedy species and other species in the same genus, which are not under cultivation. These may serve as potential sources of genes for nutritional improvement of cultivated forms. Wild species (Table 2) of solanaceous vegetable might be used as donor for crop improvement.

\section{Breeding approaches for nutritional improvement in Solanaceous Vegetables}

Evaluation of germplasm: It consists of screening of germplasm including varieties for nutritional traits along with good agronomic features. In tomato, 42 genotypes were evaluated in at 2 different locations. Pantbahar, CLN-31-0-4-2, CLN2123A, CLN2123E, CLN2143B, CLN1621L, AC1017, AC1037, AC897 were promising for TSS \% over a wide range of atmosphere (Joshi and Kohli, 2003).

Hybridization: Hybridization includes crossing between two genetically diverse genotypes. In some cases (polygenic nutritional characters), selection can also be followed after hybridization- Pedigree method of breeding. Monogenic nutritional characters can be brought into cultivated types by following back cross method of breeding. Recurrent selection is followed to increase desirable gene frequencies and to break undesirable linkages. RS and RRS for increasing TSS content in tomato.

Interspecific hybridization: High quality lines derived from such crosses usually serve as parents in hybridisation program. In tomato Lycopersicon esculentum x Lycopersicon hirsutum - high beta carotene and Lycopersicon esculentum $\mathrm{x}$ 
Lycopersicon hirsutum $f$ glabratum - also rich high beta carotene ( Kalloo, 1988).

Table 1: Disease/disorder caused by nutritional deficiency in human

\begin{tabular}{|l|l|}
\hline Constituents & Diseases/disorder caused \\
\hline Protein & Kwashiorkor and Marasmus \\
\hline carbohydrates & Kwashiorkor and Marasmus \\
\hline Vitamins & \\
\hline A & Night blindness \\
\hline B1 & Kwashiorkor and Marasmus \\
\hline B2 & Ckacking of skin \\
\hline B12 & Anaemia \\
\hline C & Scurvy \\
\hline D & Rickets \\
\hline K & Hemorrhage \\
\hline E & Sterility \\
\hline
\end{tabular}

Table 2: Wild Species

\begin{tabular}{|l|l|l|}
\hline \multicolumn{1}{|c|}{ Wild species } & Trait & Crops \\
\hline $\begin{array}{l}\text { Lycopersicon } p \\
\text { impinellifolium, } \text { L. } \\
\text { peruvianum }\end{array}$ & $\begin{array}{l}\text { Ascorbic } \\
\text { Acid }\end{array}$ & Tomato \\
\hline L.chmielewskii & $\begin{array}{l}\text { Total Soluble } \\
\text { Solids }\end{array}$ & -do- \\
\hline $\begin{array}{l}\text { Solanum. khasianum and } \\
\text { S. aviculare }\end{array}$ & solasodine & Brinjal \\
\hline $\begin{array}{l}\text { Capsicum. annuum var } \\
\text { aviculare }\end{array}$ & Capsaicin & Chilli \\
\hline Solanum microdontum & Calcium & Potato \\
\hline S.vernei & Starch & -do- \\
\hline S.phureja spp. phureja & Carotene & -do- \\
\hline
\end{tabular}

Table 3: Cultivated variety source of nutritional

\begin{tabular}{|l|l|l|}
\hline Varieties & Attribute & Crop \\
\hline $\begin{array}{l}\text { Pusa Red Plum } \\
\text { (33mg/100g) } \\
\text { Double Rich, Redrock } \\
\text { and Hisar Arun }\end{array}$ & Vitamin C & Tomato \\
\hline $\begin{array}{l}\text { Red Cherry, Novelty, } \\
\text { Angurlata, Pusa Ruby }\end{array}$ & TSS & Tomato \\
\hline $\begin{array}{l}\text { Caro Red, High } \\
\text { Pigment }\end{array}$ & $\begin{array}{l}\text { Lycopene and } \\
\text {-carotene }\end{array}$ & Tomato \\
\hline NIC 19953 & $\begin{array}{l}\text { Colour } \\
\text { extraction }\end{array}$ & chilli \\
\hline CH-3 & Vitamin C & Chilli \\
\hline $\begin{array}{l}\text { Kufri Dewa and Kufri } \\
\text { Red }\end{array}$ & Dry matter & Potato \\
\hline $\begin{array}{l}\text { Kufri Chandramukhi } \\
\text { and Kufri Sindhuri }\end{array}$ & $\begin{array}{l}\text { Protein and } \\
\text { Vitamin C }\end{array}$ & Potato \\
\hline $\begin{array}{l}\text { Kufri Chipsona 1, 2, 3, } \\
\& 4\end{array}$ & Starch & Potato \\
\hline
\end{tabular}

Table 4: Inheritance Pattern of nutritional attributes in solanaceous vegetable crops

\begin{tabular}{|l|l|l|}
\hline Attributes & Gene action & Crops \\
\hline TSS & Non additive & Tomato \\
\hline Acidity & Non additive & Tomato \\
\hline ascorbic acid & Non additive & Tomato \\
\hline $\begin{array}{l}\text { Dry matter } \\
\text { content }\end{array}$ & Over dominance & Tomato \\
\hline $\begin{array}{l}\text { carotenoids and } \\
\text { lycopene }\end{array}$ & Over dominance & Tomato \\
\hline Reducing sugar & Non additive & Tomato \\
\hline $\begin{array}{l}\text { capsaicin } \\
\text { content }\end{array}$ & $\begin{array}{l}\text { Monogenic Additive } \\
\text { gene }\end{array}$ & chilli \\
\hline Vitamin A & Additive gene & chilli \\
\hline Vitamin C & $\begin{array}{l}\text { Additive and } \\
\text { dominance gene }\end{array}$ & chilli \\
\hline Anthocynin & $\begin{array}{l}\text { Dominant } \\
\text { complementary }\end{array}$ & Brinjal \\
\hline
\end{tabular}

Table 5: Hybrids have high nutritive value

\begin{tabular}{|l|l|l|}
\hline Hybrids & Attributes & Crops \\
\hline $\begin{array}{l}\text { Arka Vikas x Sel 12, } \\
\text { KS10 x Pant T 3 \& EC } \\
818703 \times E C ~ 13042\end{array}$ & Ascorbic acid & Tomato \\
\hline $\begin{array}{l}\text { PT 10 x Pant Bahar \& } \\
\text { Pant Bahar X Pusa } \\
\text { Ruby }\end{array}$ & $\begin{array}{l}\text { TSS and } \\
\text { Ascorbic acid }\end{array}$ & Tomato \\
\hline G-2 x HS 110 & $\begin{array}{l}\text { Carotenoid } \\
\text { and Lycopene }\end{array}$ & Tomato \\
\hline $\begin{array}{l}\text { L. esculentum cv } \\
\text { Rutgers x L. hirsutum }\end{array}$ & Carotene & Tomato \\
\hline $\begin{array}{l}\text { Punjab Gucchaidar X } \\
\text { LLS }\end{array}$ & Capsaicin & Chilli \\
\hline PKM-1 x Arka Lohit & Oleoresin & Chilli \\
\hline CH-3 & $\begin{array}{l}\text { High vitamin } \\
\text { C }\end{array}$ & Chilli \\
\hline
\end{tabular}

Recent advances in breeding of solanaceous vegetables for nutritional improvement

Somaclonal variations: The generation of considerable variation, which is heritable during tissue culture is known as Somaclonal variations (Rai and Rai, 2006). Tomato variety "DNAP-9"- 20\% more soluble solids developed through using Genetic variation present in tissue cultured raised plants Transgenic and Nutritional improvement: A plant in which a foreign gene has been transferred through genetic engineering is called a transgenic plant and the gene so transferred is called transgene (Singh, 2001).

Transgenic Tomato with Enhanced Antioxidants: Roemer et al., (2000) reported that to enhance the carotenoid content and profile of tomato fruit, we

2015 ( ) Society for World Environment, Food and Technology 
have produced transgenic lines containing a bacterial carotenoid gene (crtI) encoding the enzyme phytoene desaturase, which converts phytoene into lycopene. Expression of this gene in transgenic tomatoes did not elevate total carotenoid levels. However, the betacarotene content increased about threefold, up to $45 \%$ of the total carotenoid content. Endogenous carotenoid genes were concurrently upregulated, except for phytoene synthase, which was repressed. The alteration in carotenoid content of these plants did not affect growth and development. Levels of noncarotenoid isoprenoids were unchanged in the transformants. The phenotype has been found to be stable and reproducible over at least four generations. Transgenes for low sugar in Potato: In potato today is major problem of conversion of starch in sugar during storage at low temperature $\left(0^{\circ}-4^{\circ} \mathrm{C}\right)$. To overcome this problem develop varieties possess transgenes. Two genes (ADP-GPPase and starch synthatase) are responsible for increases starch content upto 20-40 per cent in potato tuber. Source of these genes is bacteria (E. coli). However gene (Invertase inhibitor) inhibits conversion of starch to sugar during storage, it can be obtained from the Tobacco plant. Potato varieties with high starch content are needed by Food industry. Potato varieties with high sugar content leads to charring of sugar during chips making.

Creating a vitamin-rich tomato with a carrot gene: Vitamin rich tomato can be create with carrot gene in following steps:

- Copy a carrot gene which converts a pigment beta carotene

- Insertion the carrot gene into plasmid

- Reintroduction of plasmid into the Agrobacterium

- The Agrobacterium transfers the carrot gene to the cells of tomato leaves in petridish

- The tomato cells grow and divide in a culture with hormones that encourage the cells to become new shoots and roots

- As the tiny new plant grows, the carrot gene converts the tomato's pigment into beta-carotene, creating an enhanced tomato.

\section{Conclusion and Future thrust}

Germplasm should be thoroughly screened to identify major genes for nutritional as has been done in tomato, hp and ogc affecting vitamin A content. Since there is no thumb rule to assess precisely and efficiently variable germplasm and segregating generations for quality atttributes, it will be desirable that marker characters associated with quality should be identified in crops. Wild relatives of all vegetables should be evaluated for quality attributes. e.g. Lycopersicon chmielewskii has been found to possess unusually high soluble solids. Modern technologies are also playing important role in quality improvement e.g. transgenics in which no excessive or unwanted transfer of genes can occur because only the single desired gene is inserted into the new plant's DNA. Restrengthening the germplasm collection. Development of F1 hybrids, varieties and induced mutants with higher nutritional values. Exploitation of molecular biology and cellular genetics for development of transgenics with high nutritional traits. Human nutritionists must specify the objectives a breeder is expected to achieve in breeding for nutritional improvement. Incorporation of nutritional traits should be integrated with the normal breeding procedures for yield. A close interaction between nutritionists and breeder will increase the rate of progress in breeding for nutritional quality.

\section{References}

1. Anonymous, (2013). Indian horticulture database. National Horticulture Board, Ministry of Agriculture, Government of India

2. Bhattacharaya, A., Chattopadhayay, A., Mazumdar, D., Chakravarty, A. and Pal, S. (2010). International Journal of Vegetable Science. (16): 3

3. Chadha, M.L., Hedge, R.K. and Bajaj, K.L. (1988). Heterosis and combining ability studies of pigmentation in brinjal (solanum melongeona L.). Vegetable Sci. 15: 64-71

4. Joshi, A. and Kohli, U.K. (2003). Genetic divergence for different quantitative and qualitative traits in tomato (Lycopersicon esculentum Mill.). Indian J. Agric. Sci. 73(2):110-113.

5. Kalloo, G. (1986). Tomato (Lycopersicon esculentum Miller). Allied Publishers Private Ltd. New Delhi-110002

6. Kalloo, G. (1988). Vegetable Breeding. CRC Press, Florida. p. 104

7. Kalloo, G. (1998). Vegetable breeding. CRC press, Florida. p. 41

8. Rai, N. and Rai, M. (2006). Heterosis breeding in vegetable Crops. New India Publishing Agency New Delhi. pp. 546

9. Roemer, S., Fraser, P.D., Kiano, J.W., Shipton, C.A., Mills, P.B., Drake, R., Schuch, W. and Bramley, P.M. (2000). Elevation of the provitamin A content of transgenic tomato plants. Nat. Biotechnol. 18 666-669.

10. Singh, B.D. (2001). Plant Breeding Principles and method. Kalyani Publishers New Delhi110002. 